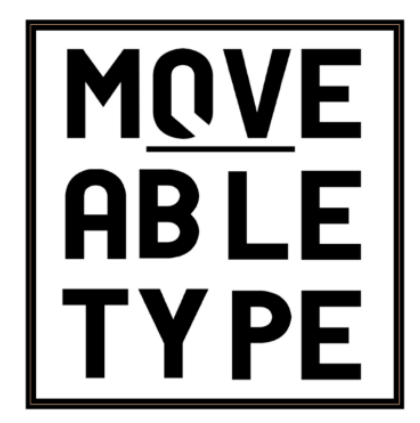

Article: Kurt Schwitters's Meræbau: Chaos, Compulsion and Creativity

Author[s]: Clare O'Dowd

Source: MoveableType, Vol. 5, 'Mess' (2009)

DOI: $10.14324 / 111.1755-4527.046$

MoveableType is a Graduate, Peer-Reviewed Journal based in the Department of English at UCL.

(C) 2009 Clare O'Dowd. This is an Open Access article distributed under the terms of the Creative Commons Attribution License (CC-BY) 4.0https://creativecommons.org/licenses/by/4.0/, which permits unrestricted use, distribution, and reproduction in any medium, provided the original author and source are credited.

\title{
UCLPRESS
}




\section{Kurt Schwitters' Merzbau: Chaos, Compulsion and Creativity}

For nearly thirty years until his death in 1948, the German artist Kurt Schwitters constructed environments for himself: self-contained worlds, places of safety, nests. Everywhere he went he stockpiled materials and built them into three-dimensional, sculptural edifices. By the time he left Hanover in 1937, heading for exile in England, Schwitters, his wife, his son, his parents, their lodgers, and a large number of guinea pigs had all been living in the midst of an enormous, detritus-filled sculpture that had slowly engulfed large parts of their home for almost twenty years. ${ }^{1}$

Schwitters was by no means the only artist to have a cluttered studio, or to collect materials for his work. So the question must be asked, what was it about Schwitters' activities that was so unusual? How can these and other aspects of his work and behaviour be considered to go beyond what might be regarded as normal for an artist working at that time? And more importantly, what were the reasons for this behaviour? In this paper, I will examine the beginnings of the Merzbau, the architectural sculpture that Schwitters created in his Hanover home. There are a number of detailed accounts of the Merzbau and its contents: Dorothea Deitrich's important study of Schwitters' collages includes a study of the iconographical elements of the Merzbau, and more recently, Elizabeth Burns Gamard's study of what she considers to be symbolic elements of the Merzbau, concentrating on an analysis of the possible mystical, alchemical and hermeneutic aspects of the sculpture. ${ }^{2}$ Gamard's study is extremely speculative, and although it accounts for some of Schwitters' more esoteric reference points within German Romantic and Expressionist traditions, the psychological implications of Schwitters' work are never fully explored. Gwendoline Webster's biographical study of Schwitters provides a surfeit of anecdotal material which, although not interpreted within the book itself, offers useful background material to support an alternative reading of Schwitters' work. ${ }^{3}$ Using Anna Freud's writings on psychological defence mechanisms, I will examine the Merzbau from a psychoanalytic perspective, as a form of defence which allowed Schwitters to maintain a level of control over his environment in the face of traumatic personal, political and social circumstances.

Kurt Schwitters decided that he had to be an artist at the age of eighteen. The decision had been reached after a long period of illness. As a boy, Schwitters had created a garden in the village of Isernhagen near Hanover, but other boys from the village destroyed his carefully tended spot. The fourteen year old Schwitters was distraught and the shock triggered an epileptic seizure, the first episode of the illness which was to last throughout his life and which left him in poor health for the following two years. ${ }^{4}$

Not for the last time, Schwitters took refuge in art. Poetry, music and painting became his new interests, and he later wrote: 
As a result of my illness, my interests changed. I became aware of my love of art. At first I wrote couplets in the style of music-hall comedians. One autumn night when the moon was full I was struck by its chill lucidity and began to write sentimental poems. Next, music seemed to me to be the art. I learned to read music and spent whole afternoons playing the piano. When I was eighteen I saw a moonlight landscape for the first time at Isernhagen and began to paint. Turned out 100 watercolours of moonlit landscapes painted by the light of a tallow candle. Then I knew I had to be a painter. ${ }^{5}$

Even allowing for Schwitters' tendency to elaborate and obfuscate in his memoirs, the implication is that all of his creative activities emerged in a compulsive, repetitive manner. As pre-eminent Schwitters scholar John Elderfield points out, Schwitters discovered art after the destruction of the idealised form of nature which he had cultivated: art could rebuild it in a new form, safe from interference. ${ }^{6}$ This early episode, and Elderfield's interpretation of it, is telling, and provides the first clues to the origins of Schwitters' later compulsion. As Anna Freud writes in her psychoanalytic exploration of defence mechanisms:

Love, longing, jealousy, mortification, pain and mourning accompany the sexual wishes, hatred, anger and rage the impulses of aggression; if the instinctual demands with which they are associated are to be warded off, these affects must submit to all the various measures to which the ego resorts in its efforts to master them, i.e. they must undergo metamorphosis. Whenever transformation of an affect occurs, whether in analysis or outside of it, the ego has been at work and we have an opportunity of studying its operations. ${ }^{7}$

This transformation of an unpleasant affect into its opposite was to become one of the defining features of the Merzbau. The idea that Schwitters could create something which would prove safe from the violence and repression of the outside world was a powerful one, allowing him to transform the anger, fear, pain and mourning he experienced into its antithesis: something he could create and control, both a sublimation and a defence.

Schwitters began his artistic education at the Hanover Kunstgewerbeschule in 1908, and his training led him from interior design in Hanover to fine art at the Royal Academy of Art in Dresden. In the summer of 1914, the Great War broke out and Schwitters, exempt from active service because of his epilepsy, returned to Hanover, filling in time by painting still lifes and landscapes, and bird watching. He had become engaged to Helma Fischer in 1909, and they finally married in 1915, moving into a flat in his parents' house. Their son Ernst was born in 1918. Schwitters was conscripted in 1917, and spent the rest of the war as a draftsman in an ironworks, where he became fascinated with machines as 'abstractions of the human mind' and started to consider the idea of the Gesamtkunstwerk: the total work of art. ${ }^{8}$ 
During the war, Schwitters started to turn his back on academic realism, and absorbed every other 'ism' he could try; Post-Impressionism, Expressionism, Fauvism, Cubism, Futurism, spending long periods in the reading room of the newly formed Kestner Society, an independent art society which exchanged catalogues with other galleries and provided up-to-date copies of art magazines. ${ }^{9}$ Within a very short time, his artistic horizons had expanded in the direction of collage, although no critic has successfully put a finger on why and how this happened. ${ }^{10}$ It can, however, be surmised that he encountered collage through the Kestner Society and the Niedersächsiches Landesmuseum in Hanover, both of which were run for a time by Alexander Dorner, who during the 1920s helped carve out a solid avant-garde reputation for the city.

Whatever the reason, it is clear that the discovery of collage was an absolute revelation to Schwitters. In its capacity to create a whole from fragments, collage could represent Schwitters' ever-present desire to unify the fragmented, to rebuild something that had been destroyed, and to control his shattered surroundings. Certainly the turmoil of Germany's situation between the wars left its mark, and the resulting guilt and helplessness experienced by the German people caused havoc: revolts, strikes, mob violence and a massive rise in crime levels. ${ }^{11}$ Yet, rather than reflecting the fragmentation and chaos as events around him spiralled out of control, Schwitters used collage as part of a complex strategy to remain in command of his own world.

Taking what was essentially rubbish - bits of paper, bus tickets, postage stamps, newspaper cuttings and advertisements - he assembled these cast-off materials into new forms, creating a new kind of order and new relationships within the selfcontained surfaces of his collages. Constantly on the lookout for materials, his new discovery began to take over his life. 'What nectar and ambrosia were to the Greek gods, glue was to Kurt Schwitters. Schwitters literally feasted on glue...' wrote Hans Arp. ${ }^{12}$

He christened his new art 'Merz', a haphazard choice which aptly sums up what he was creating. The most generally cited explanation for this name is that, while perusing one of his collages, he landed on the fragment of newspaper with the end of the word Kommerz printed on it, which seemed to encapsulate his activities. ${ }^{13}$ The term signified a new movement of Schwitters' own creation, separate from all the other 'isms' which were floating around at the time, and also included every creative pursuit in which Schwitters was involved: poetry, writing, performance, painting, collage, architecture, typography. It became his designation for the total work of art. Comments such as 'Merz means to create relationships, ideally between all things in the world, ${ }^{, 14}$ and 'my ultimate aspiration is for the union of art and non-art in the Merz total world view, ${ }^{15}$ betray Schwitters' desire to sublimate the fragmentation and helplessness that he was experiencing, and to extend the unifying properties of collage into every aspect of life. 
Schwitters' pursuit of materials for collage was relentless. There are numerous accounts of him risking life and limb, and even arrest, to gather objects and ephemera for his work. His close friend Käte Steinitz relates a story of how he was very nearly buried alive under an avalanche of waste paper from the Molling print works as he sorted through their rubbish. ${ }^{16}$ Dada artist Hans Richter tells of how Schwitters risked getting booted off a streetcar for surreptitiously removing a no-smoking sign with a screwdriver for use in future work. ${ }^{17} \mathrm{He}$ filled his studio with such detritus, and contemporary reports and photographs reveal a chaotic space:

The visitor... does not dare look up until he has reached a small spot where he is granted a somewhat obstructed view. The furnishings seem more like those of a carpentry shop than of a studio... Broken lightswitches, damaged bowties, colourful lids torn off from Camambert cheese boxes, coloured clothes buttons, and torn street car tickets are saved here with loving care... ${ }^{18}$

Schwitters later wrote that, 'everything had broken down in any case and new things had to be made out of the fragments: and this is Merz' ${ }^{19}$ As Elderfield points out, the idea of reconstituting a culture from its fragments explains Schwitters' early collage works. It does not, however, explain why Schwitters carried on using collage, why he persisted preserving the commonplace and expendable elements of the modern urban environment. ${ }^{20}$ Nor does it explain the lengths to which he went in order to gather and stockpile materials. Elderfield posits Schwitters' use of collage as a rejection of modernity, a kind of atavistic refuge which creates order from urban chaos. ${ }^{21}$ Dorothea Dietrich, in her analysis of Schwitters' collage works, describes them as an example of the simultaneous embracing and rejection of the new which characterised life in the Weimar Republic. ${ }^{22}$ Similarly, Gamard acknowledges the problematic relationship that Schwitters had with modernism: despite modernism's claims to totality and consolidation, Schwitters' work stands necessarily apart from this due to the explicit impurity of its materials and process. ${ }^{23}$ However, the hoarding of materials that characterises Schwitters' activities at that time suggests a much deeper crisis, one which goes beyond Schwitters' superficial relationship with the conditions of modernity. If Schwitters were not an artist, and did not have the rationalization that these materials might come in useful for future collages, his behaviour might have been viewed very differently.

A useful way to examine the complex motives behind Schwitters' work is through an understanding of compulsive hoarding. Although Schwitters' activities were part of a rich and ambitious artistic strategy, his persistent and often disruptive hoarding behaviour can certainly be viewed in terms of a more deep-rooted coping strategy. Compulsive hoarding is a relatively new category, into which research has only recently been carried out. Hoarding, as a variant of Obsessive Compulsive Disorder, has been defined as '(1) the acquisition of, and failure to discard, possessions which appear to be useless or of limited value; (2) living spaces sufficiently cluttered so as to preclude activities for which those spaces were designed; (3) significant distress or 
impairment in functioning caused by the hoarding, ${ }^{24}$ The reasons for hoarding behaviour centre upon indecisiveness, concern over mistakes, judgements about need and emotional attachment to possessions. ${ }^{25}$ Hoarding behaviour is reinforced by providing a sense of control over the environment, by avoiding making decisions, and by avoiding the emotional consequences of parting with a possession. ${ }^{26}$ When most of us save or discard possessions, we make a judgement about whether or not the item will be useful in the future, whether the item can be replaced if necessary, and how much the item means to us emotionally. In cases of compulsive hoarding, different beliefs about the risks or consequences of discarding items, or their future value or emotional significance are held, resulting in a compulsion to retain items outside of the scope which might be considered normal.

One of the most significant findings of the research into compulsive hoarding is the level and the type of attachment that hoarders have with regard to their possessions. It has been found that most hoarders derive a sense of safety from being surrounded by their possessions, and that they are very concerned about maintaining control over their environment. ${ }^{27}$ Research shows that hoarders feel a greater sense of responsibility, both for themselves, those close to them, and their possessions, which are given quasi-human status. ${ }^{28}$ It is these two aspects of compulsive hoarding that I believe are most important in understanding Schwitters' work.

Anna Freud has written extensively on the role of defence mechanisms in anxiety disorders such as OCD and compulsive hoarding, and her work contributes to the understanding of these conditions in terms of reaction formation in the development of symptoms. Defence mechanisms, for Anna Freud, are developed by the ego as a means of protecting itself, whether from unwanted instinctual impulses, such as those that characterise OCD, or the emotional affects associated with them. ${ }^{29}$ In OCD, the impulses form the obsessional component, often leading to the compulsive or ritualised behaviour: for example a fear of disease or contamination leads to compulsive cleaning or handwashing. Unwelcome impulses or affects are transformed into their opposites: anxiety into aggression, envy into over-confidence. This reversal, the change from one behaviour or emotion to its opposite, are measures taken by the ego against external dangers by actively intervening to change the conditions of the world around it. As I will demonstrate, this kind of measure is exactly the sort undertaken by Schwitters as he transformed his own environment.

An important characteristic of compulsive hoarding is the idea that the hoarded items might come in handy one day. An exaggerated sense of responsibility drives hoarders to keep items 'just in case'. For Schwitters, this was justified to an extent by his need to work, by his very real responsibility to provide for his wife and family. His creative powers were their main source of income, and the drive to hoard must stem in part from pure economics. Other anecdotal examples though, demonstrate a sense of having to be prepared which is so often a feature of compulsive hoarding, and which results in hoarders carrying around with them what they believe to be potentially 
useful materials. ${ }^{30}$ Schwitters travelled a great deal during his career, giving lectures and performances and taking part in various Dada soirees. Steinitz, amongst others, recalls how he always travelled with a suitcase containing food and cooking utensils, and artist Werner Graeff learned the hard way during one expedition when he offered to help Schwitters with his ludicrously heavy baggage - only to find out that it was full of 'horseshoes, stones and that sort of thing'. 31

Schwitters was also notorious for stockpiling, and not just in his own house. Artist Hannah Höch described how Schwitters left stocks of found objects at friends' houses, including hers, so that he had something to work with on his next visit. ${ }^{32}$ Steinitz described how he used her basement as a repository for books, pictures and magazines. ${ }^{33}$ The persistent, chronic nature of Schwitters' hoarding activities suggests two things; firstly, a profound need to assert himself as provider and protector, and secondly a deep-seated desire to control his environment. There are some welldocumented reasons for the emergence of these characteristics in Schwitters' case, and both of these requirements could be satisfied through his artistic output.

The political situation in Germany after the end of the war was a turbulent one. The surrender of the German armies, the burden of reparations imposed by the Treaty of Versailles and the questions over the country's political future left wounds which festered throughout the post-war years. The effect of such instability and confusion on the German people, not only combatants but civilians, was severely damaging. Guilt, loss of identity and soon, economic collapse were taking their toll on German citizens as the newly formed Weimar Republic failed to reach any sort of consolidation of its splintered politics. ${ }^{34}$

Throughout this time, Schwitters had been living and working in the same place, in his studio at the family home in Hanover. This chaotic space was crammed full of collages and materials, and at one point during 1919, soon after the birth of Merz, Schwitters' close friend Käte Steinitz describes the appearance of a new Merz assemblage:

One day something appeared in the studio which looked like a cross between a cylinder or wooden barrel and a table-high stump with the bark run wild. It had evolved from a chaotic heap of various materials: wood, cardboard, scraps of iron, broken furniture, and picture frames. Soon, however, the object lost all relationship to anything made by man or nature. Kurt called it a 'column'. 35

The emergence of the Merzcolumn in Kurt Schwitters' studio coincided with a period of immense trauma and upheaval, both personal and political. It began, as Käte Steinitz describes, with the appearance of the heap of materials which expanded in all directions. The column, or columns, were certainly well established by 1919 when Richard Huelsenbeck stayed with the Schwitters family for Christmas: 
Schwitters showed us his workroom, which contained a tower. This tower or tree or house had apertures, concavities, and hollows in which Schwitters said he kept souvenirs, photos, birthdates, and other respectable and less respectable data. The room was a mixture of hopeless disarray and meticulous accuracy. You could see incipient collages, wooden sculptures, pictures of stone and plaster. Books, whose pages rustled in time to our steps, were lying about. Materials of all kinds, rags, limestone, cuff links, logos of all sizes, newspaper clippings.

We asked him for details, but Schwitters shrugged: 'It's all crap...,36

At the top of one column sits the head of a tiny baby, ${ }^{37}$ the significance of which was not known for many years but which was later revealed by Ernst Schwitters to be the death mask of the artist's first son who died shortly after birth. ${ }^{38}$ This personal tragedy, which occurred in 1916, ${ }^{39}$ affected Schwitters deeply, and in his work of that time there is a pronounced theme of loss and mourning. It is particularly evident in the sculpture of a woman (believed to be Helma) which he exhibited in the Kunstverein show of 1917 called Leiden (Suffering), and in a further portrait of Helma, Trauernde (Mourning Woman), which was shown at the Kestner Society exhibition of May that year. $^{40}$ In 1918, the year before the column was initiated, Schwitters wrote the poem Grünes Kinde (Green Child), a heartbreakingly sad poem about protecting a child who is running from danger. The poem is generally regarded as an example of the influence of Expressionist and particularly Sturm poetic techniques that Schwitters was using in his work at the time, but the subject matter is highly emotional and speaks volumes about the effect on the artist of this loss.

It becomes clear then, that the initial development of the Merzcolumn was more than simply a sculptural experiment. It was a memorial to his dead son, and the tiny mask atop the column can be seen in photographs of Schwitters' studio for many years afterwards. ${ }^{41}$ The death of his son, I believe, brought the full force of Schwitters' protective instincts to bear, instincts which manifested themselves in the hoarding and protection of objects, beginning with Gerd Schwitters' death mask. If Schwitters could not preserve his son, then he could certainly protect his memory.

The fact that the mask remained visible is tangible evidence of its importance, given the development of the rest of the column. When Hans Richter, who remained friends with Schwitters for many years, visited the house in 1925, the column had been expanded almost to fill the room on the second floor in which it now resided, and reached almost to the ceiling. He described it as 'more than a sculpture; it was a living, daily-changing document on Schwitters and his friends'. ${ }^{42}$ The description that Huelsenbeck had written describing the state of the column in 1919 still rang true in 1925, as Richter related: 
He explained it to me and I saw that the whole thing was an aggregate of hollow space, a structure of concave and convex forms which hollowed and inflated the whole sculpture.

Each of these individual forms had a 'meaning'. There was a Mondrian hole, and there were Arp, Gabo, Doesburg, Lissitsky, Malevich, Mies van der Rohe and Richter holes. A hole for his son, one for his wife. Each hole contained highly personal details from the life of one of these people. He cut off a lock of my hair and put it in my hole... ${ }^{43}$

The column had become 'an autobiographical depository', to use John Elderfield's description, and was evidently by now an immovable structure which had begun the process of mutating into an environmental construction. ${ }^{44}$ The original column had, over the following three years, gone beyond what could be dismissed merely as the result of a cluttered studio, and in what Elderfield describes as a new route to the Gesamtkunstwerk, Schwitters began to join the Merzcolumn and other sculptures to his studio walls by building materials out to meet them. ${ }^{45}$ The artist's son describes the initial process which began the transformation of the first Merzcolumn and the three following columns into the niches and grottoes described by Richter:

His pictures would decorate the walls, his sculptures standing along the walls. As anybody who has ever hung pictures knows, an interrelation between the pictures results. Kurt Schwitters, with his particular interest in the interaction of the components of his work, quite naturally reacted to this. He started by tying strings to emphasise this interaction. Eventually they became wires, then were replaced by wooden structures which, in turn, were joined with plaster of Paris. This structure grew and grew and eventually filled several rooms on various floors of our home, resembling a huge abstract grotto. ${ }^{46}$

This 'huge, abstract grotto' was the Merzbau. ${ }^{47}$ The iconographical contents of the Merzbau cover a variety of themes, from spaces designated for particular friends or other individuals to those reflecting current events and particular conditions in Hanover. ${ }^{48}$ However, the capacity of his art to create a unified whole from shattered fragments was now extended to the intimate details of his own life. The earlier collage works, the Merzbilder, had been a way for Schwitters to exert some control in the face of chaos, but the loss of his son had struck at the very core of his identity: it had eroded his own powers of creativity and therefore the essence of his identity as an artist. He was now pouring himself - literally, in some elements - into the enormous construction which became his life's work. ${ }^{49}$ As Schwitters put it in 1931, the Merzbau encompassed 'the development into pure form of everything that has struck me as important or unimportant over the last seven years...' 50 The Merzbau's secondary designation was the Kathedrale des erotischen Elends (KdeE) or Cathedral of Erotic Misery, so named after one of Schwitters' earlier columns. The KdeE certainly provided a church-like sanctuary for Schwitters. By 1923 the situation in the 
outside world had become increasingly unpleasant. Rocketing inflation had precipitated the German financial crisis and the French were occupying the Ruhr. Hitler's putsch had narrowly failed and already there were unsettling signs that National Socialism was on the rise. It seems to have been the trials of 1923 in particular which heralded the beginning of the Merzbau as environmental structure. ${ }^{51}$ Indeed, although Schwitters' typography and advertising businesses, along with the money he made from poetry recitals, kept the family's heads above water, the 1923 crisis seriously affected the art market and he was barely selling any work. ${ }^{52}$

By this point Schwitters had begun to incorporate representative items belonging to friends and family into the Merzbau. If, as I have described, hoarders imbue objects with 'quasi-human status', it would make sense for Schwitters to incorporate them into the sanctuary of the Merzbau. The structure, which by 1927 had taken over Ernst's playroom and was beginning to expand into other areas of the house, certainly seems to have been a site for the safe-keeping of items of a more or less personal nature. Items begged, stolen or borrowed from friends made their way into its niches and grottoes, ${ }^{53}$ but other spaces were devoted to issues which simply fascinated Schwitters, and which could be explored within the private space of the Merzbau. Die Missbilliggenerheldhöhle (Cave of the Deprecated Heroes) and Die Lustmordhöhle (the Cave of the Sex Murders) are two examples, both of which reflect current events and particular conditions in Hanover after the war, at a time when the rate of sex crimes saw a marked rise and, as Deitrich describes, the psychological disorientation of veterans returning home after the deprivations of war was aggravated by a shift in male-female relations. ${ }^{54}$ Certainly Weimar Germany was a society very much affected by such issues, and this was reflected in the work of a number of artists, most notably George Gross and Otto Dix. ${ }^{55}$ The Dada movement as a whole had notoriously misogynist tendencies, at the same time as being preoccupied with sexual liberation, a freedom that would have been somewhat difficult for Schwitters to explore within the confines of what was essentially a happy marriage. ${ }^{56}$ So the Merzbau became a space where Schwitters could explore some of the more unsavoury ideas which were floating around in his head at the time, away from prying eyes in an environment which was under his complete control. It also became a place for the preservation of memories, and of the objects which represented his family and friends. Above all, the Merzbau was a kind of nest, a place of safety, where he could escape from the unpleasantness of real life.

The formal development of the Merzbau had been closely linked to the artistic circles in which Schwitters moved: in its earlier years it had reflected his ties to the Dada group, in its chaotic use of assemblage; in later years, as Schwitters became involved with Constructivism, the outward appearance of the structure changed and assumed a much more geometric and sparse façade. The inner grottoes and niches still held the original material, but had been effectively obliterated by Schwitters' enthusiastic use of plaster and white emulsion. Although the outward appearance of the Hanover Merzbau had altered considerably by the late twenties, this should not necessarily be taken as an 
indication that Schwitters' state of mind had altered. The Hanover Merzbau was not the only Merzbau, and by 1932 Schwitters had begun to effect the same process of transformation upon a small hut that his family rented during holidays on the island of Hjertøy in Norway. ${ }^{57}$ Indeed, wherever Schwitters went he undertook the same process: in exile in Norway in 1937 he began a new Merzbau at Lysaker; attempts were made to transform his sleeping quarters in Hutchinson Camp on the Isle of Man where he and his son were interned as enemy aliens; and finally Ambleside in the Lake District, where he eventually settled in the 1940s, saw the beginnings of a final Merz project, the Merzbarn. ${ }^{58}$ In each case, as circumstances became more threatening or unpleasant for Schwitters, the Merzbau and its descendants developed as part of a coping mechanism, and the creation of a safe environment in such circumstances was a repetitive element throughout Schwitters' life.

The late twenties and early thirties were certainly traumatic for Schwitters. The political situation had been deteriorating for a while in Hanover, as Schwitters' friend Sophie Lissitzky-Küppers recounted: a lecture she attended back in 1925 by Theodore Lessing had been interrupted by right-wing protesters. ${ }^{59}$ By 1933 the Nazis had made it into government. Elsewhere in Germany 'Degenerate Art' exhibitions were already being held in provincial towns and Schwitters' work was included in them. ${ }^{60}$ As the insidious rise of Nazism continued throughout the late twenties and early thirties, Schwitters was gradually compelled to withdraw from the vibrant art scene of which he had become a part, and to retreat into isolation. By 1934 he was sleeping in the Merzbau, having deserted his own bedroom. ${ }^{61}$ His contacts in the art world were either fleeing the country, lying low or being arrested, and when a Gestapo spy infiltrated the Hanover socialist resistance movement in 1936 over 300 people, including close friends of Schwitters, ended up facing trial. ${ }^{62}$ Hitler's infamous Entartete Kunst (Degenerate Art) exhibition toured Germany in 1937 and Schwitters was amongst the hundred and twelve artists whose works were labelled as 'the products of insanity, of impudence, of ineptitude, and of decadence'. ${ }^{63}$ A succession of people had fled Germany, including Schwitters' close friends the Steinitzes, Lissitsky, and Hausmann, whilst others like Hannah Höch were forced to lie low simply in order to survive as the Nazi drive to cleanse culture of degenerate modernism resulted in the wholesale persecution of artists and their associates. An additional and very serious threat was posed by Schwitters' epilepsy, which was fourth on the list of conditions which the Nazis intended to eradicate: one attack in public and Schwitters would have been in considerable trouble. ${ }^{64}$ In 1937 Schwitters was summoned to appear before the Hanover Gestapo as a 'witness' in what he presumed was the trial of his friends Christoph and Luise Spengeman and their son Walter. ${ }^{65}$ This was something he was not prepared to do, and thus his fate was sealed: he was now in exile.

The events of Schwitters' life were undoubtedly catalytic in terms of his behaviour: the early distress of his illness, the collective scars of the First World War, the personal tragedy of the death of his son, the threat posed to modern art and artists by the Nazis, and the trials and traumas of exile and internment. There was little peace in 
Schwitters' life. His coping strategy, facilitated by contemporaneous developments within avant-garde art, was firstly to hoard objects in order to exert some control over his environment and to demonstrate an ability to protect, and then secondly to construct an environment over which he could have complete control and within which he could find sanctuary. In short, the creation of the Merzbau was wholly necessary for Schwitters. Indeed, Anna Freud's model suggests that controlling an environment in this way, to provide a sense and place of safety, would be a transformative action, capable of overturning the unwelcome affects of helplessness, vulnerability and anger, and allowing Schwitters to express a degree of power and authority over his world in circumstances which left him very little of either.

\section{CLARE O'DOWD}

Clare O'Dowd is currently researching her doctoral thesis at the University of Manchester, examining relationships between art, architecture, psychology and sociology. She has recently completed an internship at the Whitworth Art Gallery, working on the acclaimed Subversive Spaces exhibition, and has previously published in Papers of Surrealism. 
${ }^{1}$ I shall refer throughout to images of the Merzbau which can be found in the Catalogue Raisonné, ed. by Karin Orchard and Isabel Schulz, 3 vols (Hanover: Hatje-Cantz and the Sprengel Museum, 20012005)

${ }^{2}$ See Dorothea Dietrich, Tradition and Innovation: The Collages of Kurt Schwitters, (Cambridge:

Cambridge University Press, 1993) and Elizabeth Burns Gamard, Kurt Schwitters' Merzbau (New York: Princeton Architectural Press, 2000)

${ }^{3}$ Gwendoline Webster, Kurt Merz Schwitters (Cardiff: University of Wales Press, 1997)

${ }^{4}$ Amongst other sources this story is related in Werner Schmalenbach, Kurt Schwitters, (London:

Thames and Hudson, 1967), p. 28

${ }^{5}$ Original text in Sturm-Bilderbuch IV: Kurt Schwitters (Berlin: Der Sturm, 1920). Translated in

Schmalenbach p. 28

${ }^{6}$ John Elderfield, Kurt Schwitters (London: Thames and Hudson, 1985), p. 20

${ }^{7}$ Anna Freud, The Ego and the Mechanisms of Defence (London: Hogarth Press, 1961) p. 34

${ }^{8}$ Schmalenbach, pp. 30-32

${ }^{9}$ See Curt Germundson, 'Kurt Schwitters and the Alternative Art Community', from Crisis in the Arts, Dada: Cologne and Hanover, ed. by Charlotte Stokes and Stephen Foster (New York: GK Hall, 1998), pp. 207-209 for more on the Kestner Society

${ }^{10}$ Webster, p. 39 The author is explicit about this lack of a concrete explanation. Other authors merely acknowledge that Schwitters used collage, not precisely why or how he came to do so: see

Schmalenbach, p. 89, Elderfield, pp. 28, 35 and Dietrich, pp. 18-19.

${ }^{11}$ See 'The Legacy of the War' and 'Revolution and the Birth of the New Republic' in Kaes and others, The Weimar Republic Sourcebook (Berkeley: University of California Press, 1994), pp. 5-25 and pp. 35-56,

${ }^{12}$ Schmalenbach, p. 90

${ }^{13}$ Ernst Schwitters gives this explanation in Schwitters (exhibition cat., London: Marlborough Fine Arts, Mar - April 1963), p. 6

${ }^{14}$ Original text in 'Merz', Der Sturm, 1927, reprinted in Kurt Schwitters: Das literarische Werk,(Vol 5: Manifeste und kritische Prosa) ed. by Friedhelm Lach, 5 vols (Cologne: DuMont, 1981), p 192, translated in R. Burmeister, 'Related Opposites: Differences in mentality between Dada and Merz' from Kurt Schwitters' Merz: a total vision of the world (exhibition cat., Bern: Benteli and, Museum Tinguely, $1^{\text {st }}$ May $-22^{\text {nd }}$ Aug 2004), p. 147

${ }^{15}$ Original text in Sturm-Bilderbucher IV, translated in Schmalenbach, p. 104

${ }^{16}$ Käte Steinitz, Kurt Schwitters: A Portrait From Life (Berkeley: University of California Press, 1968), pp. 38-39

${ }^{7}$ Quoted in Webster, p. 106. On the following pages Webster provides a large number of anecdotes from various friends of Schwitters regarding what can only be interpreted as hoarding behaviour.

${ }_{18}$ The newspaper reporter Alfred Dudelsack visited Schwitters's studio in 1920, quoted here in Deitmar Elger, 'Kurt Schwitters: Merzbau in Hanover', in Crisis in the Arts, Dada: Cologne and Hanover, ed. by Stokes and Foster, p. 194. See Catalogue Raisonné, II, No. 1199 (Fig. 12-14), Kathedrale des erotischen Elends

${ }^{19}$ Original text from 'Kurt Schwitters', in Gefesselter Blick, ed. by Heinz and Bodo Rasch (Stuttgart:

Wissenschaftlicher, 1930), reprinted in Das literarische Werk, V, p. 335, translated in Schmalenbach, p. 32

${ }^{20}$ Elderfield, pp. 90-91

${ }^{21}$ Elderfield, pp. 91-92

${ }^{22}$ Dietrich, p. 136

${ }^{23}$ Gamard, pp. 5-6

${ }^{24}$ R. Frost and T. Hartl, 'A Cognitive-Behavioural Model of Compulsive Hoarding', Behaviour

Research and Therapy, 34.4 (1996), 314-350 (p. 341)

${ }^{25}$ Frost and Hartl, p. 381

${ }^{26}$ Frost and Hartl, pp. 380-381

${ }^{27}$ See Frost and others, 'The value of possessions in compulsive hoarding: patterns of use and attachment', Behaviour Research and Therapy, 33.8 (1995), 897-902

${ }^{28}$ See Frost and others, pp. 901

${ }^{29}$ Freud, pp. 32-44

${ }^{30}$ See Frost and others, p 901 
${ }^{31}$ Steinitz, p 18 and Webster, p. 125

${ }^{32}$ Webster, p. 140

${ }^{33}$ Steinitz, p. 87

${ }^{34}$ Kaes and others, pp. 5-6

${ }^{35}$ Steinitz, p. 90. See Catalogue Raisonné, I, No. 769, Untitled Merzcolumn in Studio, 1923)

${ }^{36}$ Richard Huelsenbeck, Memoirs of a Dada Drummer (Berkeley: University of California Press, 1974), p. 66

${ }^{37}$ Accounts do not agree on this issue: Elderfield, pp. 144-145, Webster, p. 210, and Gamard, figs 2425 all give different accounts, and different columns are cited as the First Day Merzcolumn. The descriptions quoted by Steinitz and Huelsenbeck do not seem to match either, so one can conclude that there were many columns which were eventually incorporated into the Merzbau. The column topped with the mask of Gerd Schwitters became a central part of the Merzbau as later photographs demonstrate: see Catalogue Raisonné, II, No. 1199 (Fig. 6), Untitled (Merzcolumn, 1923-25) ${ }^{38}$ Elderfield, p. 159

${ }^{39}$ Again, there are disagreements as to the date: see Webster, p. 30 and Gamard, pp. 52-53. Elderfield does not mention a date, and Schmalenbach does not refer to Schwitters' first child at all.

${ }^{40}$ Webster, pp. 30-32. See Catalogue Raisonne, I, No. 154, Trauernde (Mourning Woman), 1917

${ }^{41}$ See Catalogue Raisonné, II, No. 1199 (Fig. 10), Untitled (Column with Boy's Head, part of Merz Building, 1925) and detail view, 1932, large plate p. 288

${ }^{42}$ Hans Richter, Dada: Art and Anti-Art (London: Thames and Hudson, 1965), p. 152

${ }^{43}$ Richter, p. 152

${ }^{44}$ Elderfield, pp. 146-147

${ }^{45}$ Elderfield, p. 143

${ }^{46}$ Quoted in Elderfield, p. 148

${ }^{47}$ Catalogue Raisonné, II, No. 1199 (Figs. 15-28), Merzbau, 1930-32 and large plates pp. 288-291

${ }^{48}$ The iconographical elements of the Merzbau are covered extensively in the work of Dietrich and Gamard. See in particular Gamard, pp. 87-114 and Dietrich, pp.163-205

${ }^{49}$ Indeed, one of the more puzzling items in the Merzbau was a bottle of Schwitters' own urine, which he describes as offering "reassurance". For many early psychoanalysts, hoarding behaviour was linked to the anal-erotic character, and was closely associated with an inability to part with one's bodily waste: see Ernest Jones, 'Anal-Erotic Character Traits' (1918) in Papers on Psychanalysis, $5^{\text {th }}$ edn (London: Maresfield, 1977), pp. 413-437, and Karl Abraham, 'Contributions to the theory of the anal character' (1921), in Selected Papers (London: Maresfield, 1988), pp. 370-406

${ }^{50}$ Quoted in Schmalenbach, p. 130

${ }^{51}$ Elderfield, p. 147

${ }^{52}$ The effect of the financial crisis on Germany's artists and intellectuals is discussed in B. Widdig, Culture and Inflation in Weimar Germany (London: University of California Press 2001), see especially the introduction pp. 3-30 and 'Cultural Capital in Decline: Inflation and the Distress of Intellectuals', pp. 169-195. Widdig makes the link between inflation and mass culture, and demonstrates the breakdown of barriers between high and low culture which is particularly relevant in terms of Schwitters' work.

${ }^{53}$ See Elderfield, p. 160: Schwitters often availed himself of his friends' possessions for inclusion in the Merzbau.

${ }_{55}^{54}$ Gamard, p. 97 and Dietrich, p. 193

${ }^{55}$ For further discussion of how these issues were reflected in the art produced in Weimar Germany, see M. Tatar, Lustmord: Sexual murder in Weimar Germany (Princeton: Princeton University Press, 1995)

${ }^{56}$ For further exploration of this see B. Lewis, 'Lustmord: Inside the windows of the Metropolis' in Berlin: Culture and Metropolis, ed. by Charles Haxthausen and Heidrun Suhr (Minneapolis: University of Minnesota Press, 1990), pp. 111-140. Kurt and Helma Schwitters' marriage seems to have been a genuinely happy one but was disrupted on various occasions by his predilection for pretty girls: see Webster, pp. 261-269 and Steinitz, pp. 89-95

${ }^{57}$ See Catalogue Raisonné, II, No. 1864 (Figs. 1-16), Untitled (Hut on Hjertøy), 1932-39

${ }^{58}$ See Catalogue Raisonné, III, No. 2327 (Figs. 1-4), Haus am Bakken (House on the Hill) at Lysaker, 1937, and Number 3659 (Figs. 1-14), Merzbarn. Accounts of Schwitters' attempt to 'merz' his sleeping quarters in Hutchinson Camp using stale porridge and found objects can be found in Klaus Hinrichson's 'Visual Art Behind the Wire' in The Internment of Aliens in Twentieth Century Britain, ed. by David Cesarani and Tony Kushner (London: Frank Cass, 1993), pp. 202-203, and in Elderfield, p. 205

${ }_{59}$ Sophie Lissitzky-Küppers El Lissitzky: Life, Letters, Texts (London: Thames and Hudson, 1968) p61 
${ }^{60}$ Webster, pp. 253-254

${ }^{61}$ Webster, p. 264

${ }^{62}$ Webster, p. 274

${ }^{63}$ Adolf Ziegler's speech at the opening of the exhibition, July $19^{\text {th }} 1937$, quoted in Henry Grosshans, Hitler and the Artists (New York: Holmes and Meier, 1983), p. 105

${ }^{64} \mathrm{P}$. Weindling, Health, race and German politics between national unification and Nazism, 1870-

1945 (Cambridge: Cambridge University Press, 1989), pp. 525-526

${ }^{65}$ Webster, p. 279 